\title{
Recurrent Fatal Hydrops Fetalis Associated with a Nucleotide Substitution in the Erythrocyte $\beta$-Spectrin Gene
}

\author{
Patrick G. Gallagher, ${ }^{\ddagger}$ Scott A. Weed, $\$$ William T. Tse, " Lori Benoit," Jon S. Morrow," Sally L. Marchesi," \\ Narla Mohandas, ${ }^{* *}$ and Bernard G. Forget ${ }^{ \pm \|}$ \\ Departments of *Pediatrics, ${ }^{\ddagger}$ Internal Medicine, ${ }^{\S}$ Cell Biology, "Pathology, and ${ }^{\natural}$ Genetics, Yale University School of Medicine, \\ New Haven, Connecticut 06437; and **Cell and Molecular Biology Division, Lawrence Berkeley Laboratory, \\ University of California, Berkeley, California 94720
}

\begin{abstract}
We studied a kindred in which four third-trimester fetal losses occurred, associated with severe Coombs-negative hemolytic anemia and hydrops fetalis. Postmortem examination of two infants revealed extensive extramedullary erythropoiesis. Studies of erythrocytes and erythrocyte membranes from the parents revealed abnormal erythrocyte membrane mechanical stability as well as structural and functional abnormalities in spectrin, the principal structural protein of the erythrocyte membrane. Genetic studies identified a point mutation of the $\beta$-spectrin gene, S2019P, in a region of $\beta$ spectrin that is critical for normal spectrin function. Both parents and two living children were heterozygous for this mutation; three infants dying of hydrops fetalis were homozygous for this mutation. In an in vitro assay using recombinant peptides, the mutant $\beta$-spectrin peptide demonstrated a significant abnormality in its ability to interact with $\alpha$ spectrin. This is the first description of a molecular defect of the erythrocyte membrane associated with hydrops fetalis. (J. Clin. Invest. 1995. 95:1174-1182.) Key words: hemolysis - hereditary elliptocytosis - membrane skeleton • spectrin • hydrops fetalis
\end{abstract}

\section{Introduction}

Nonimmune hydrops fetalis (NIHF) ${ }^{1}$ is an important cause of perinatal pregnancy loss, with mortality approaching $100 \%$ in some series (1-7). The development and implementation of preventive methods for $\mathrm{Rh}$ hemolytic disease of the newborn has led to a relative increase in the incidence of NIHF in nonAsian populations (6). NIHF has been associated with a myriad

Address correspondence to B. G. Forget, M.D., Hematology Section, Department of Internal Medicine, Yale University School of Medicine, WWW 4, 333 Cedar Street, P.O. Box 208021, New Haven, CT 065208021. Phone: 203-785-4144; FAX: 203-785-7232. W. T. Tse's present address is Department of Pediatrics, Stanford University School of Medicine, Stanford, CA 94305.

Received for publication 28 July 1994 and in revised form 31 October 1994.

1. Abbreviations used in this paper: DI, deformability index; GST, glutathione $S$-transferase; HE, hereditary elliptocytosis; HPP, hereditary pyropoikilocytosis; NIHF, nonimmune hydrops fetalis.

J. Clin. Invest.

(c) The American Society for Clinical Investigation, Inc.

0021-9738/95/03/1174/09 \$2.00

Volume 95, March 1995, 1174-1182 of conditions, but in many cases the etiology is unknown. Advances in both prenatal diagnostic and therapeutic techniques, as well as detailed pathologic studies, have combined to improve the understanding of the diagnoses in many cases (7). This, in turn, combined with advances in neonatal care, has improved the outcome in some cases.

Hematologic disorders are responsible for $\sim 10 \%$ of cases of NIHF. This includes disorders of hemoglobin synthesis, primarily homozygous $\alpha$ thalassemia, selected erythrocyte enzymopathies, and parvovirus B19 infection. Although abnormalities of the erythrocyte membrane skeleton have been suspected in cases of NIHF $(8,9)$, only one well-documented case has been reported (8). In this case, virtually absent synthesis of the erythrocyte membrane skeleton protein $\alpha$ spectrin was detected, although the specific molecular lesion responsible for the defect in protein synthesis is yet to be elucidated. Near-fatal neonatal hemolytic anemia has also been associated with cases of recessive hereditary spherocytosis and homozygous hereditary elliptocytosis/pyropoikilocytosis (HE/HPP) (10-17).

The erythrocyte membrane skeleton is responsible for maintaining the shape and deformability of the erythrocyte. Qualitative and quantitative disorders of membrane skeleton proteins have been associated with abnormalities of red blood cell shape including hereditary spherocytosis, HE, and HPP. A number of structural abnormalities of spectrin, the major structural component of the erythrocyte membrane, have been associated with HE and HPP (for reviews see references 15 and 18-21). Spectrin is composed of two structurally similar but nonidentical proteins, $\alpha$ and $\beta$ spectrin. $\alpha$ and $\beta$ spectrin are composed primarily of homologous 106 -amino acid repeats that fold into three antiparallel $\alpha$-helices connected by short nonhelical segments $(22,23), \alpha$ and $\beta$ spectrin combine to form dimers, which in turn self-associate to form tetramers and higher order oligomers. These tetramers and oligomers form a lattice-like structure that is critical for erythrocyte membrane stability as well as erythrocyte shape and deformability.

This report describes a Laotian kindred in which four thirdtrimester fetal losses occurred, associated with severe Coombsnegative hemolytic anemia and extensive extramedullary erythropoiesis. Postmortem examination of two infants revealed overt hydrops fetalis. Studies of erythrocytes and erythrocyte membranes from the parents revealed abnormal membrane mechanical stability as well as structural and functional abnormalities in spectrin. Genetic studies identified a point mutation of the $\beta$-spectrin gene resulting in an amino acid replacement, $\mathrm{S} 2019 \mathrm{P}$, in the $\mathrm{COOH}$-terminal region of erythrocyte $\beta$ spectrin $(\beta 1 \Sigma 1)$ that is critical for normal spectrin self-association. Both parents and two living children were heterozygous for this mutation. Three deceased infants, as determined by analysis of DNA 


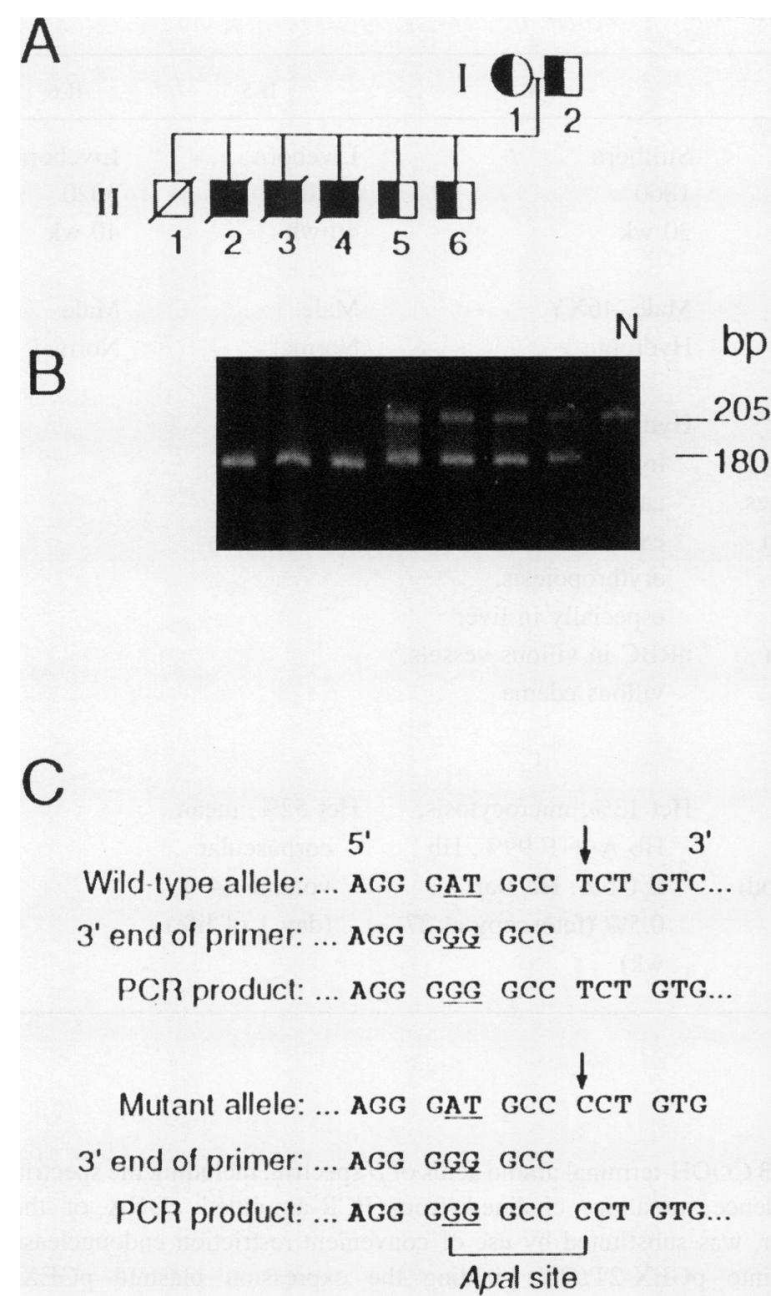

Figure 1. Pedigree of family and detection of the spectrin Providence mutation. $(A)$ Family pedigree. The diagonal lines through the symbols indicate stillborn or perinatally deceased hydropic infants. $(B)$ Genomic DNA corresponding to the region of exon 30 of the $\beta$-spectrin gene encoding the mutation was amplified by PCR using an antisense primer that creates an Apal site only when the mutant spectrin Providence allele is present. ApaI-digested amplification products were fractionated by electrophoresis in a 5\% agarose gel. A band of 205 bp indicates a normal ( $\mathrm{ApaI}^{-}$) $\mathrm{PCR}$ product, a band of $180 \mathrm{bp}$ indicates a mutant $\left(\mathrm{ApaI}^{+}\right)$PCR product. The parents and two children, I-1, I-2, II-5, II6, are heterozygous for the mutation; three hydropic infants, II-2, II-3, and II-4, are homozygous for the mutation. There is no digestion of normal control $(N)$ amplification products. The relevant DNA sequences of the PCR primer and genomic DNA that form the basis for this assay are shown in $C$.

obtained from autopsy material, were homozygous for the mutation. In an in vitro assay using recombinant peptides, the mutant $\beta$-spectrin peptide demonstrated a profound abnormality in its ability to interact with $\alpha$ spectrin. We have named this variant spectrin Providence.

\section{Methods}

\section{Family study}

Infants of the spectrin Providence kindred were products of an apparently nonconsanguineous mating of a Laotian couple (Fig. $1 A$ ). Clinical and hematologic information regarding these infants is shown in Table I. Of note is the fact that there was evidence of marked extramedullary erythropoiesis in the first four infants (Fig. 2), all deceased, with infants II-3 and II-4 exhibiting overt hydrops fetalis. Hematologic studies performed on the parents (Table II) revealed that both parents had mild elliptocytosis and that the father was heterozygous for both hemoglobin E trait and $\alpha$-thalassemia trait. Hemoglobin electrophoresis of a cord blood sample from infant II-3 and of a fetal blood sample from infant II-4, obtained by fetoscopy at $\sim 27$ wk of gestation, definitively excluded the diagnosis of homozygous $\alpha$ thalassemia. In addition, both of these fetal blood samples showed evidence of severe anemia. The fetal blood sample of infant II-4 was characterized by marked microcytosis, with a red cell size distribution significantly smaller than that of his mother, as displayed by oscilloscope readout of an electronic cell sizer (Coulter Corp., Hialeah, FL). Blood smear revealed marked microcytosis, spherocytosis, polychromatophilia, poikilocytosis with red cell fragmentation, and presence of numerous nucleated red blood cells. Serial antibody determinations, performed over the course of $10 \mathrm{yr}$ on maternal blood, were negative. Further studies to determine the etiology of the hemolytic anemia and hydrops fetalis are detailed below.

\section{Mechanical stability of erythrocyte membranes}

Resealed membranes were prepared by a procedure adapted from Johnson (24). The erythrocytes were washed three times in $5 \mathrm{mM}$ Tris ( $\mathrm{pH}$ 7.4 ), $14 \mathrm{mM} \mathrm{NaCl}$ and then lysed in $40 \mathrm{vol}$ of $7 \mathrm{mM} \mathrm{NaCl}$ and $5 \mathrm{mM}$ Tris ( $\mathrm{pH} 7.4$ ). The membranes were then pelleted by centrifugation,

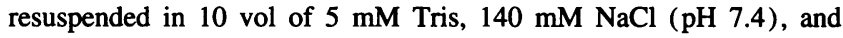
incubated for $30 \mathrm{~min}$ at $37^{\circ} \mathrm{C}$ for resealing. For mechanical stability measurements, $150 \mu \mathrm{l}$ of the membrane suspension was mixed with 3.5

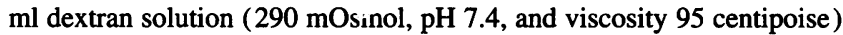
and subjected continuously to $750 \mathrm{dyn} / \mathrm{cm}^{2}$ in the ektacytometer (25). Under this stress, the membranes progressively fragment, generating undeformable spheres. This process is detected as a time-dependent decrease in the deformability index (DI). The rate of decline of DI is a measure of membrane mechanical stability.

\section{Studies of erythrocyte membrane proteins}

Erythrocyte membrane preparation and quantitation. Erythrocyte membranes were prepared from peripheral blood as described previously $(26,27)$. Membrane proteins were separated by SDS-PAGE in 3.5$17 \%$ gradient polyacrylamide gels and stained with Coomassie blue. Spectrin/band 3 ratios were obtained by scanning the stained gels using the Personal Densitometer Laser Scanner (Molecular Dynamics, Sunnyvale, CA) and then calculating the total volume of protein/band using Imagequant software (Molecular Dynamics).

Limited tryptic digestion of spectrin. Spectrin was extracted by incubating ghosts overnight at $4^{\circ} \mathrm{C}$ in low ionic strength buffer (28). Limited tryptic digests of spectrin extracts were prepared as described (26) and separated by two-dimensional fractionation using SDS-PAGE and isoelectric focusing as modified by Speicher et al. (29).

Study of spectrin self-association. The amount of spectrin dimers compared with spectrin tetramers in spectrin extracted from membranes under conditions of low ionic strength at $4^{\circ} \mathrm{C}$ was determined by nondenaturing gel electrophoresis as described (30).

\section{Molecular genetic analyses}

Preparation of genomic DNA, RNA, and CDNA. DNA was extracted from $5-\mu \mathrm{m}$ thick sections taken from paraffin blocks prepared from autopsy tissue of three infants, II-2, II-3, and II-4, as described (31). Genomic DNA was isolated from leukocytes or an amniotic fluid cell line (infant II-4) as described by Sahr et al. (32). RNA was isolated from hemolysates of anticoagulated peripheral blood as described (33). cDNA was prepared from total RNA by reverse transcription as described by Tse et al. (33).

Oligonucleotide synthesis and amplification of cDNA and genomic DNA. Synthetic oligonucleotides were synthesized using an automated synthesizer (Applied Biosystems, Foster City, CA) and purified by gel 
Table I. Infants of Spectrin Providence Kindred

\begin{tabular}{|c|c|c|c|c|c|c|}
\hline & II-1 & II-2 & II-3 & II-4 & II-5 & II-6 \\
\hline & Stillborn & Stillborn & Liveborn & Stillborn & Liveborn & Liveborn \\
\hline Birthweight (g) & 2764 & 1900 & 2010 & 1860 & 3020 & 3020 \\
\hline $\begin{array}{l}\text { Gestational age } \\
\text { (date) }\end{array}$ & Unknown & $33 \mathrm{wk}$ & $\begin{array}{l}30 \mathrm{wk} \text {, died at } 13 \\
\text { min of age }\end{array}$ & $30 \mathrm{wk}$ & $40 \mathrm{wk}$ & $40 \mathrm{wk}$ \\
\hline Sex & Male & Male & Male, $46 \mathrm{XY}$ & Male, $46 \mathrm{XY}$ & Male & Male \\
\hline $\begin{array}{c}\text { Appearance } \\
\text { (gross) }\end{array}$ & Autolysed & Autolysed & Hydropic & Hydropic & Normal & Normal \\
\hline Autopsy & None & None & $\begin{array}{l}\text { Hydrothorax, } \\
\text { pulmonary } \\
\text { hypoplasia, ascites, } \\
\text { cardiac dilatation }\end{array}$ & $\begin{array}{l}\text { Hydrothorax, pulmonary } \\
\text { hypoplasia, ascites, } \\
\text { cardiac dilatation, } \\
\text { extreme amount of } \\
\text { erythropoiesis, } \\
\text { especially in liver }\end{array}$ & & \\
\hline Placenta & Erythroblastic & $\begin{array}{l}\text { wt } 720 \mathrm{~g} \text {, nRBC } \\
\text { in villous } \\
\text { vessels, villous } \\
\text { edema }\end{array}$ & $\begin{array}{l}\text { wt } 647 \mathrm{~g}, \mathrm{nRBC} \text { in } \\
\text { villous vessels, } \\
\text { villous edema }\end{array}$ & $\begin{array}{l}\mathrm{nRBC} \text { in villous vessels, } \\
\text { villous edema }\end{array}$ & & \\
\hline $\begin{array}{l}\text { Laboratory studies } \\
\text { (time of sample) }\end{array}$ & & & $\begin{array}{l}\text { Hct } 6 \% \text {, no } \\
\text { detectable Hb } \\
\text { Bart's (cord blood) }\end{array}$ & $\begin{array}{l}\text { Hct } 13 \%, \text { microcytosis, } \\
\text { Hb A + F } 99 \%, \mathrm{Hb} \\
\text { E } 0.5 \%, \text { Hb Bart's } \\
0.5 \% \text { (fetoscopy at } 27 \\
\text { wk) }\end{array}$ & $\begin{array}{l}\text { Hct } 52 \%, \text { mean } \\
\text { corpuscular } \\
\text { volume } 84 \mathrm{fl} \\
\text { (day } 1 \text { of life) }\end{array}$ & \\
\hline
\end{tabular}

$n R B C$, nucleated red blood cells; Hct, hematocrit.

electrophoresis or oligonucleotide purification column chromatography (Applied Biosystems). The sequences of the primers used in PCR and sequencing are: $\alpha$-spectrin, exon 2: 5'-CGTGAATTCTGAGAACTAGCAATTAACAG-3' (sense, intronic), 5'-CGTGGATCCCCATTAACATTAACATAAAG-3' (antisense, intonic); $\beta$-spectrin exons 30+31: 5'-GCGAATTCAGGAGTGAACGATTGGGTGCT-3' (sense, intronic), 5'-CGAAGCTTGGTCCCAATGTCAGGT-3' (antisense, intonic); and $\beta$-spectrin, exon 32: 5'-GCGAATTCGCAGGAGGCTCTGGCCT-3'(sense, intronic), 5'-CGAAGCTTGCGCAGCTCATCTCGCCT-3' (antisense, intonic). Subcloning and sequencing of PCR-amplified cDNA and genomic DNA were completed as described $(16,32)$.

$P C R$-based mutation detection. Oligomer primers were synthesized corresponding to the sequence of $\beta$-spectrin cDNA. The sense primer was designed with the dinucleotide GG substituted for the normal AT at positions $-4 /-5$ from its $3^{\prime}$ end corresponding to codon 2018 of $\beta$-spectrin mRNA, 5'-GGTGTGCCAGTTCTCGAGGGGGGCC-3 (sense, exonic; cDNA positions 6125-6149). After PCR with a downstream antisense primer, 5'-CTGTTCCCTGCTCACCGTGGTG-3' (antisense, intronic), an ApaI site, GGGCCC, will be created at codon 2019 (the site of the nucleotide substitution) only if the mutant allele is amplified (Fig. $1 B$ ). Digestion of amplification products with Apal followed by agarose gel electrophoresis allowed determination of presence or absence of the mutant spectrin Providence allele in genomic DNA.

\section{Analysis of recombinant $\beta$-spectrin peptides}

Construction of $\beta$-spectrin expression plasmids. The prokaryotic expression vector pGEX-2T was used to generate recombinant $\beta$-spectrin peptides for spectrin self-association assays (34). Plasmid pGEX-2T $\beta 28$ contains the cDNA encoding the COOH-terminal $\sim 40 \%$ of the normal $\beta$-spectrin chain (35); the encoded recombinant peptide has been shown to associate with both native $\alpha \beta$ spectrin dimers and with the $80-\mathrm{kD} \alpha \mathrm{I}$ domain peptide of $\alpha$ spectrin at levels comparable with that of native $\beta$ spectrin (36). To incorporate the spectrin Providence mutation into this expression plasmid, a 369 -bp $\beta$-spectrin gene fragment encoding the $123 \mathrm{COOH}$-terminal amino acids of $\beta$ spectrin, including the spectrin Providence mutation, obtained from PCR-amplified cDNA of the mother, was substituted by use of convenient restriction endonuclease sites into pGEX-2T $\beta 28$, yielding the expression plasmid pGEX$2 \mathrm{~T} \beta 28 \mathrm{P}$. Nucleotide sequencing confirmed the presence of the mutation at codon 2019 as well as the absence of PCR-induced sequence alterations in the cDNA insert of the plasmid.

Preparation of proteins. Recombinant proteins were expressed in bacteria and purified as described previously $(35,36)$. Native $\alpha \beta$ spectrin dimers were purified from human erythrocyte ghosts by extraction at low ionic strength. The $80-\mathrm{kD} \alpha$-spectrin univalent peptide was obtained by limited tryptic digestion of native spectrin by immunoaffinity purification using a monoclonal antibody ( $\mathrm{mAb}$ II D2) bound to Sepharose (36). All proteins were further purified by HPLC using $27.5 \times 300$ mm Sephrogel-TSK G3000 gel filtration columns (Pharmacia LKB Biotechnology, Inc., Piscataway, NJ) in series. ${ }^{125}$ I-labeling of the $80-\mathrm{kD}$ fragment of $\alpha$ spectrin was performed by the lactoperoxidase method using Enzymobeads (Bio-Rad Laboratories, Richmond, CA).

Spectrin self-association assay. Both the $\beta 28$ and $\beta 28 \mathrm{P}$ fusion proteins were assayed for their ability to associate with the univalent 80$\mathrm{kD}$ peptide by ligand affinity chromatography (36). Bound, labeled ligand was estimated by scanning densitometry of autoradiograms and by counting in a $\gamma$-scintillation counter.

\section{Results}

\section{Mechanical stability of erythrocyte membranes}

The mechanical stability and rigidity of erythrocyte membranes were examined using an ektacytometer. Ektacytometric measurements of mechanical stability of membranes derived from erythrocytes of both parents and one live-born child are shown in Fig. 3. The rate of decline of DI (a measure of mechanical stability) of membranes from all three subjects was much faster 

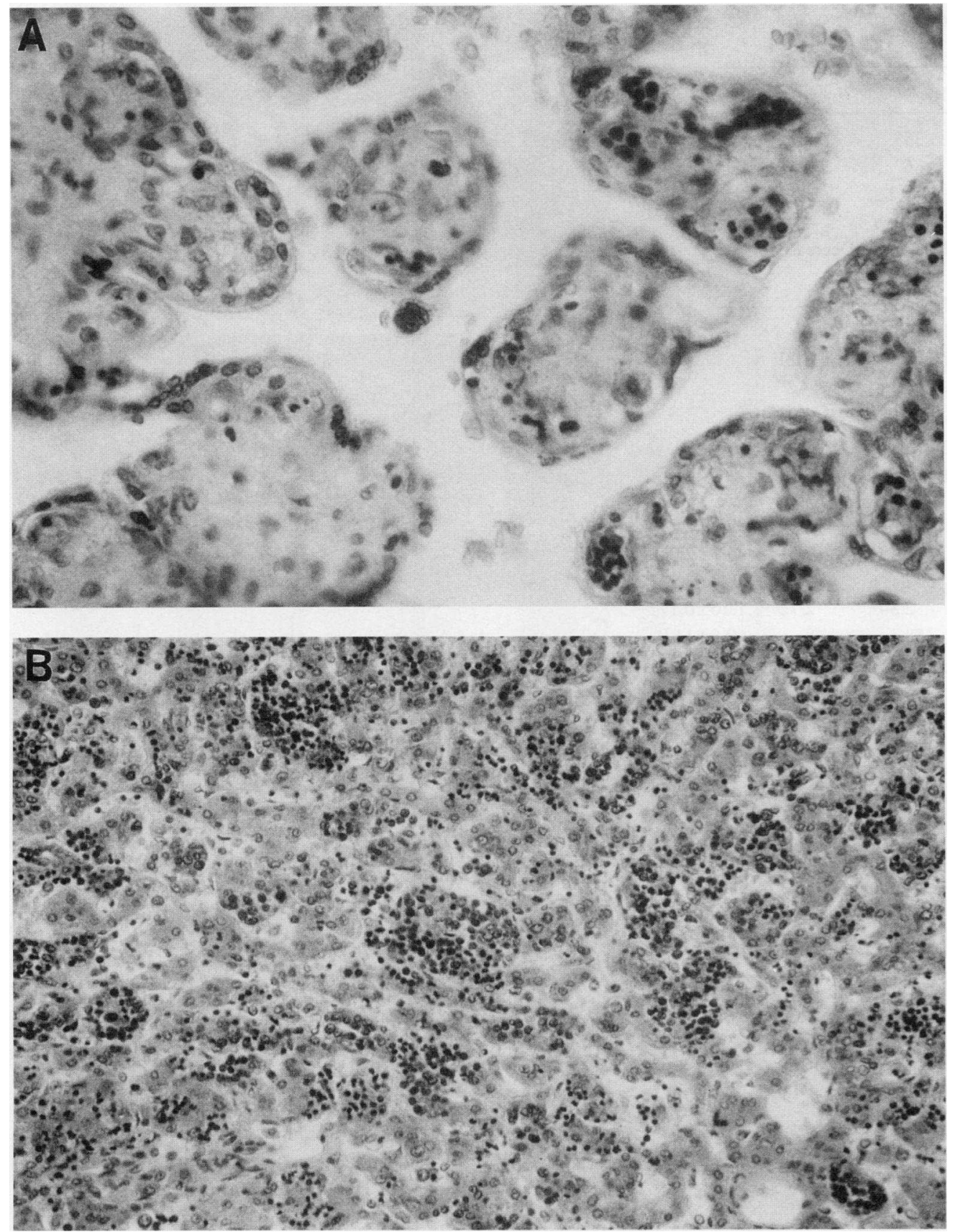

Figure 2. Histopathology of tissues from hydropic infants. $(A)$ Section of placenta (hematoxylin and eosin, $\times 10$ ) from infant II-2 stillborn at 33 wk of gestation and $(B)$ section of liver (hematoxylin and eosin, $\times 40$ ) from infant II-4 stillborn at 30 wk of gestation. Both sections reveal extensive extramedullary erythropoiesis, as shown by the multiple nucleated red blood cells. than that of normal membranes, implying a marked decreased in mechanical stability of these membranes. As shown in Fig. 3 , the observed decrease in mechanical stability of these membranes was intermediate between membranes of erythrocytes from a heterozygous individual with an $\alpha$-spectrin gene mutation causing nonhemolytic $\mathrm{HE}$ and those from an individual doubly heterozygous for two different $\alpha$-spectrin gene mutations causing hemolytic HE or HPP (37). Membranes from all three subjects were also abnormally rigid, compared with normal membranes, their membrane dynamic rigidity was increased two- to threefold (data not shown).

\section{Studies of erythrocyte membrane proteins}

Qualitative and quantitative analyses of erythrocyte membrane proteins. One-dimensional SDS-PAGE analyses of erythrocyte membrane proteins from the mother, father, and infant II-6 were qualitatively normal (data not shown). Quantitative analysis of spectrin content, measured by the ratio of spectrin/band 3, was normal in the mother (0.97), the father (1.17), and infant II-6 (0.97), compared with a normal control (1.04).

Limited tryptic digestion of spectrin. After limited digestion with trypsin followed by two-dimensional gel electrophoresis, normal spectrin can be resolved into five $\alpha$ and four $\beta$ major proteolytically resistant domains $(29,38,39)$. The amino terminus of $\alpha$ spectrin, the $80-\mathrm{kD} \alpha \mathrm{I}$ domain, interacts with the carboxy terminus of $\beta$ spectrin, the $28-\mathrm{kD} \beta$ I domain, to form the binding site for spectrin self-association. Limited tryptic digestion of spectrin followed by two-dimensional fractionation using SDS-PAGE and isoelectric focusing (Fig. 4) revealed increased amounts of a 74-kD $\alpha$-spectrin peptide in both parents 
Table II. Laboratory Studies on Parents of Spectrin Providence Kindred

\begin{tabular}{|c|c|c|c|}
\hline & I-1, Mother & I-2, Father & \\
\hline Hematocrit (\%) & 35 & 38 & \\
\hline Mean corpuscular volume (fl) & 86 & 60 & \\
\hline Reticulocyte count (\%) & 1.2 & 1.8 & \\
\hline Antibody screen & Negative & - & \\
\hline Incubated osmotic fragility & Normal & Decreased & \\
\hline \multicolumn{4}{|l|}{ Parvovirus antibody } \\
\hline IgG & Negative & - & \\
\hline IgM & Negative & - & \\
\hline Hemoglobin electrophoresis & Normal & $\begin{array}{c}21 \% \mathrm{HbE} \\
+\mathrm{A} 2\end{array}$ & \\
\hline$\beta / \alpha$ globin chain synthetic ratio & 1.08 & 0.85 & \\
\hline $\begin{array}{c}\text { Erythrocyte enzyme assays } \\
\left(\mathrm{IU} / \mathrm{g} \mathrm{Hb} \text { at } 37^{\circ} \mathrm{C}\right)\end{array}$ & & & (Normal) \\
\hline Glucose-6-phosphate & & & \\
\hline dehydrogenase & 11.64 & 12.3 & $12.1 \pm 2.1$ \\
\hline Pyruvate kinase & 14.99 & 9.51 & $15.0 \pm 2.0$ \\
\hline Phosphoglycerate kinase & 332 & 419 & $320 \pm 36$ \\
\hline Hexokinase & 2.54 & 2.72 & $1.16 \pm 0.17$ \\
\hline Glucose-phosphate isomerase & 58.1 & 48 & $60.8 \pm 11.0$ \\
\hline
\end{tabular}

and a living child (II-6). This peptide is derived from the normal $\mathrm{NH}_{2}$-terminal $80-\mathrm{kD}(\alpha \mathrm{I})$ peptide of $\alpha$ spectrin and is frequently seen in increased amounts in certain cases of HE and HPP, usually associated with structural defects of the amino

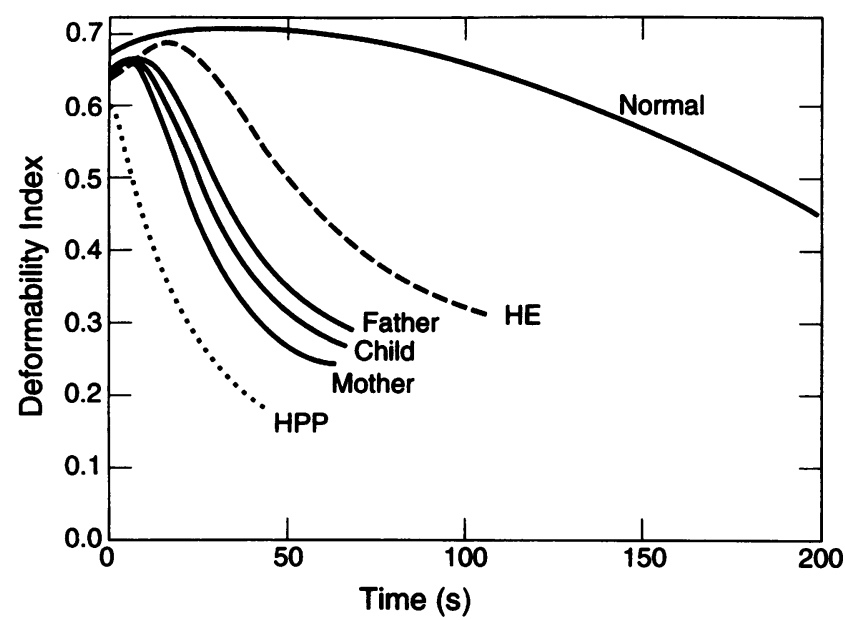

Figure 3. Ektacytometric analysis of mechanical stability of erythrocyte membranes. Resealed ghosts prepared from normal and mutant red cells were subjected to shear stress in an ektacytometer, and the decline of DI was measured as a function of time. The rate of DI decline is a measure of membrane mechanical stability. Red cell membranes from both parents and one child (II-5) heterozygous for spectrin Providence fragmented more rapidly than normal membranes. The fragmentation curves of these membranes were intermediate between those previously reported for nonhemolytic heterozygous HE and for hemolytic elliptocytosis due to homozygous HE or HPP associated with mutations of the $\alpha$-spectrin gene.

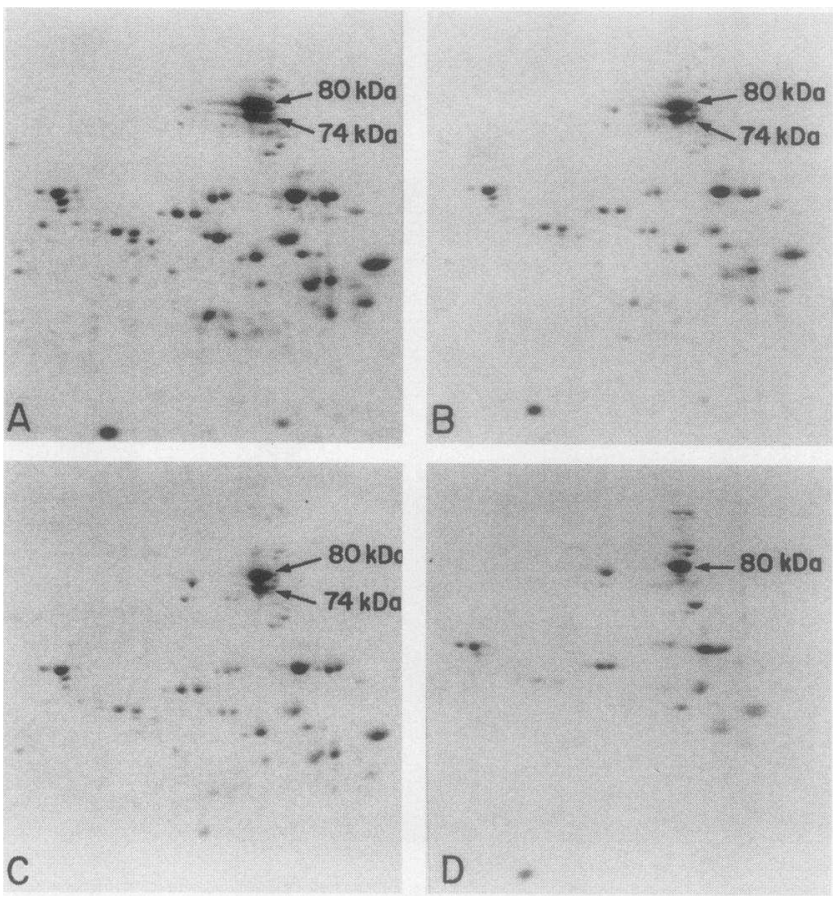

Figure 4. Limited tryptic digestion of spectrin. Red cell spectrin from members of the spectrin Providence kindred was partially digested with trypsin and fractionated by two-dimensional SDS-PAGE. Spectrin digests from the family show the normal $80-\mathrm{kD} \alpha$-spectrin peptide and markedly increased amounts of the 74-kD $\alpha$-spectrin peptide compared with normal. $A$, mother; $B$, father; $C$, living child II-6; and $D$, normal control.

terminus of $\alpha$ spectrin or, more rarely, with structural defects of the carboxy terminus of $\beta$ spectrin (19).

Spectrin self-association assays. Studies of spectrin selfassociation were performed using spectrin extracted from erythrocytes under conditions of low ionic strength at $4^{\circ} \mathrm{C}$. The increased amount of spectrin dimers compared with tetramers obtained in extracts of the parent's erythrocyte membranes ( Table III) indicates a moderate degree of impairment of spectrin self-association in these individuals. In general, the severity of impairment of spectrin self-association parallels the clinical severity of patients with HE or $\operatorname{HPP}(15,40)$.

\section{Molecular genetic analyses}

PCR amplification and DNA sequencing. Nucleotide sequence analysis of subcloned, amplified genomic DNA fragments de-

Table III. Spectrin Dimer/Tetramer Ratio at Different Spectrin Concentrations

\begin{tabular}{lccc}
\hline \multicolumn{3}{c}{ Spectrin dimer/tetramer ratio } \\
& \multicolumn{3}{c}{ Spectrin concentration } \\
\cline { 2 - 4 } & $9 \mathrm{mg} / \mathrm{ml}$ & $14 \mathrm{mg} / \mathrm{ml}$ & $1 \mathrm{mg} / \mathrm{ml}$ \\
\hline Father & 0.31 & 0.34 & 0.50 \\
Mother & 0.43 & 0.46 & 0.65 \\
Control & 0.15 & 0.23 & Not done
\end{tabular}




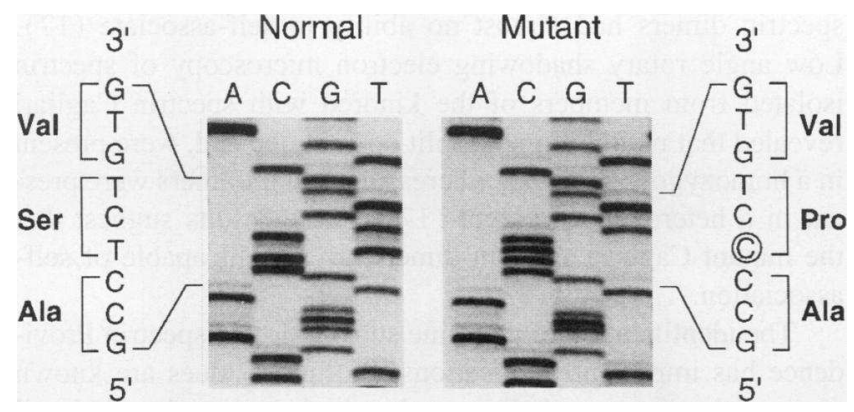

Figure 5. Nucleotide sequence of PCR-amplified genomic DNA of the mother of the spectrin Providence kindred. Genomic DNA was amplified by PCR using primers corresponding to exon 30 of the $\beta$-spectrin gene. The PCR products were subcloned, and individual clones were sequenced. In approximately half of the subclones, a point mutation was detected that changes a serine (TCT) to proline (CCT) at codon 2019 of the $\beta$-spectrin gene.

rived from proband II-4 and his mother revealed a single base substitution (TCT to $\underline{\mathrm{CCT}}$ ) that changes a serine to a proline at position 2019 of the $\beta$-spectrin chain (Fig. 5). This mutation occurs at position 40 of repeat 17 within helix 1 of the proposed triple helical model of spectrin repeats $(22,23,41,42)$, corresponding to position A12 of the crystallographic structure of the spectrin repeat (23). The majority of mutations of the 80$\mathrm{kD} \alpha \mathrm{I}$ domain of spectrin occurs in helix three of the proposed model and is often at or adjacent to highly conserved residues of the homologous 106-amino acid repeats of spectrin (18-21).

To ensure that other HE mutations frequently associated with the variant $\alpha$ I 74-kD peptide were not present in members of the spectrin Providence kindred (see below), we examined the regions of the $\alpha$ - and $\beta$-spectrin genes encoding the selfassociation site that have been associated with this variant peptide, i.e., exon 2 of the $\alpha$-spectrin gene and exons 30 and 31 of the $\beta$-spectrin gene $(32,42,43)$. The nucleotide sequences of all three of these exons were normal in PCR-amplified DNA obtained from both parents and infant II-4.

Detection of the nucleotide substitution by PCR-generated restriction endonuclease site. The authenticity of the spectrin Providence mutation was confirmed by restriction enzyme digestion of amplified genomic DNA. A synthetic, partial artificial Apal site was designed in the sense primer to allow differentiation of mutant ( $\mathrm{ApaI}^{+}$) and normal (ApaI ${ }^{-}$) alleles (Fig. 1 C). The results of these studies are shown in Fig. $1 \mathrm{~B}$. The mother, father, and two living children, II-5 and II-6, are heterozygous for the spectrin Providence mutation. Three deceased infants, II-2, II-3, and II-4, are homozygous for the mutation, as determined by ApaI digestion of PCR-amplified DNA obtained from tissue blocks prepared for pathologic examination. Material was not available from infant II-1.

\section{Analysis of recombinant $\beta$-spectrin peptides}

To further establish that the Providence mutation was directly responsible for the reduced self-association activity, normal $(\beta 28)$ and mutant $(\beta 28 \mathrm{P})$ recombinant $\beta$-spectrin peptides were assayed in vitro for their ability to bind to the univalent 80-kD $\alpha \mathrm{I}$ domain spectrin peptide. Previous results demonstrated that binding of the normal $\beta 28$ recombinant peptide to

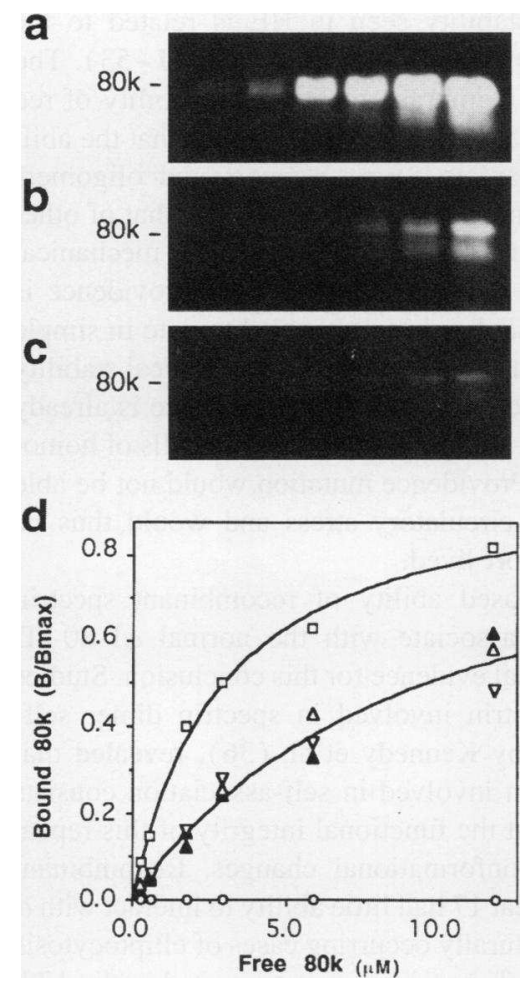

Figure 6. Binding of normal and mutant recombinant $\beta$-spectrin peptides to native $80-\mathrm{kD} \alpha$-spectrin peptide. Fixed amounts of normal $(\beta 28)$ or mutant $(\beta 28 \mathrm{P})$ recombinant fusion peptides, corresponding to the $\mathrm{COOH}$-terminal $\sim 40 \%$ of the $\beta$-spectrin chain attached to glutathione $S$-transferase (GST), were incubated with increasing amounts (lanes 1-6, 1.1, 2.3, 6.9, $11.5,23$, and $46 \mu \mathrm{g}$, respectively) of ${ }^{125}$ I-labeled $80-\mathrm{kD} \alpha$-spectrin peptide fragment. The amount of bound $\alpha$-spectrin peptide (80k) retained by affinity chromatography on a glutathione-agarose column was quantitated following SDS-PAGE. Autoradiograms of the resulting gels are shown: $(a)$ nor-

mal $\beta 28$ fusion peptide; (b) mutant $\beta 28 \mathrm{P}$ fusion peptide; $(c)$ control GST recombinant peptide without $\beta$-spectrin fusion partner. $d$ shows the nonlinear regression analysis of binding capacity: squares, normal $\beta 28$ fusion peptide $\left(K_{\mathrm{d}}, 2.93 \pm 0.9 \mu \mathrm{M}\right)$; triangles (three different assays), mutant $\beta 28 \mathrm{P}$ fusion peptide $\left(K_{\mathrm{d}}, 9.49 \pm 4.1 \mu \mathrm{M}\right)$; circles, control GST recombinant peptide (no significant binding). Binding data were normalized to unit stoichiometry $\left(B / B_{\max }\right)$. All experimental points were assayed in triplicate.

the $80-\mathrm{kD}$ peptide is equivalent to that of native spectrin tetramer (36). As shown in Fig. 6, the $\beta 28 \mathrm{P}$ mutant recombinant peptide displayed a threefold reduction in binding affinity compared with the $\beta 28$ wild-type recombinant peptide.

\section{Discussion}

In many patients with HE and HPP, limited tryptic digestion of spectrin followed by two-dimensional gel electrophoresis has revealed abnormal or enhanced proteolytic cleavage of the 80$\mathrm{kD}$ peptide of the $\alpha \mathrm{I}$ domain (19), such as the variant $74-\mathrm{kD}$ peptide present in spectrin digests of members of this kindred. Frequently, mutations are found near the site of abnormal proteolytic cleavage (30). Most of these structural abnormalities lead to decreased ability of spectrin dimers to self-associate into tetramers and oligomers. The $74-\mathrm{kD}$ variant peptide is most commonly associated with $\alpha$-spectrin mutations. However, as in this case, mutations in the $\mathrm{COOH}$-terminal region of $\beta$ spectrin may be associated with the mutant $74-\mathrm{kD}$ peptide $(13,33$, 44-50). In these latter cases, it has been proposed that abnormal proteolytic cleavage of the $80-\mathrm{kD} \alpha \mathrm{I}$ domain occurs as a result of the disruption of the coiled-coil interaction present in a fusion triple helical repeat segment created by the association of the ends of the $\alpha$ - and $\beta$-spectrin chains (13).

Previous studies have shown that the extent of decrease in 
membrane mechanical stability seen in $\mathrm{HE}$ is related to the degree of defective spectrin self-association $(37,51-53)$. The severity of the defect in membrane mechanical stability of red cells heterozygous for spectrin Providence implies that the ability of this spectrin variant to form tetramers and oligomers must be significantly compromised compared with that of other previously identified $\alpha$ - and $\beta$-spectrin mutants. The mechanical dysfunction observed in red cells with spectrin Providence is by far the most severe that has been observed to date in simple heterozygotes for a spectrin variant. As the mechanical stability of red cells of heterozygotes for spectrin Providence is already severely compromised, it is highly likely that red cells of homozygotes for the spectrin Providence mutation would not be able to withstand significant circulatory stress and would thus be extremely fragile and short lived.

The markedly decreased ability of recombinant spectrin Providence peptides to associate with the normal $\alpha \mathrm{I} 80-\mathrm{kD}$ peptide provides additional evidence for this conclusion. Studies of the region of $\beta$ spectrin involved in spectrin dimer selfassociation, carried out by Kennedy et al. (36), revealed that the $\beta$-spectrin subdomain involved in self-association consists only of repeat 17 and that the functional integrity of this repeat is highly sensitive to conformational changes. Recombinant peptides truncated in repeat 17 had little ability to interact with $\alpha$ spectrin. A number of naturally occurring cases of elliptocytosis have been reported with $\beta$-spectrin chains truncated in the 17th repeat $(33,46,47,49,50,54)$. Truncation mutations have only been reported in the heterozygous state, perhaps because of the low gene frequency of these mutations and the very low incidence of at-risk pregnancies. One could hypothesize that these truncation mutants would be lethal in the homozygous state. Additionally, the studies of Kennedy et al. (36) revealed that the additional $\mathrm{COOH}$-terminal sequences (i.e., domain III) characteristic of erythroid $\beta$ spectrin $(\beta \mathrm{I} \Sigma 1)$, the muscle isoform of erythroid $\beta$ spectrin $(\beta \mathrm{I} \Sigma 2)$, and $\beta$ fodrin $(\beta \mathrm{II})$ (a homologous nonerythroid protein) did not alter spectrin selfassociation; only repeat 17 was important. The importance of serine 2019 (residue 40 of repeat 17) is highlighted by its conservation at this position of repeat 17 in all vertebrate $\beta$ spectrins reported to date including human $\beta$ fodrin (55), canine $\beta$ spectrin (56), murine $\beta$ spectrin (57), and murine $\beta$ fodrin (58).

Two other amino acid substitutions have been described in repeat 17 of $\beta$ spectrin and both have occurred in the homozygous state: spectrin Kayes ${ }^{2}$ (A2053P) (13) and spectrin Cagliari (A2018G) (17) affecting the residue immediately adjacent to that mutated in spectrin Providence (S2019P). Both mutants exhibit findings similar to spectrin Providence. Heterozygous individuals are clinically asymptomatic; their erythrocytes have normal spectrin content and a mild to moderate defect in spectrin self-association. Homozygous individuals exhibit severe hemolysis and anemia necessitating frequent blood transfusions until splenectomy in early childhood; red cells from these individuals exhibit a severe defect in spectrin self-association. In a patient homozygous for spectrin Cagliari, $95 \%$ of the spectrin in membrane extracts was dimeric, indicating that the mutant

2. This $\beta$-spectrin variant has been retrospectively named according to the city of origin of the family in agreement with Dr. M. Garbarz and Dr. D. Dhermy. spectrin dimers had almost no ability to self-associate (17). Low angle rotary shadowing electron microscopy of spectrin isolated from members of the kindred with spectrin Cagliari revealed that mainly dimers, split open at one end, were present in a homozygous proband, whereas normal tetramers were present in a heterozygous parent (17). These results suggest that the mutant Cagliari spectrin dimers are also incapable of selfassociation.

The identification of a proline substitution in spectrin Providence has important implications. Proline residues are known to severely disrupt $\alpha$-helices and perturb potential coiled-coil interactions (59). A number of proline substitutions in spectrin leading to impaired self-association with resultant elliptocytosis have been described (19). The proline substitution in spectrin Providence most likely impairs both intrachain interactions between helix 1 and helix 2 of the $\beta$-spectrin chain (helix A and helix B of Yan et al. [23]) at the head of the spectrin dimer, thereby altering the conformation of the $\alpha$-spectrin binding site, and interchain hydrophobic and ionic interdimer interactions between $\alpha$ and $\beta$ spectrin. In spectrin Cagliari, the only other helix 1 mutation reported, an $\alpha$-helical destabilizing glycine substitution, probably also disrupts both interchain and intrachain interactions in a similar manner.

As mentioned above, the relative incidence of NIHF is increasing, underscoring the importance of thorough prenatal and postnatal diagnostic testing. Because NIHF may recur, as was the case in this kindred, such studies can have an important impact on future pregnancies. In this case, diagnostic studies were performed over a $>10$-yr span, using techniques that were not available when the family first came to attention. Such tools could now provide prenatal diagnosis for this kindred, if desired.

Thorough followup of abnormal findings should be performed in cases of NIHF. In this kindred, the discovery of extramedullary erythropoiesis at autopsy directed further investigation into a possible hematologic cause of the hydrops fetalis. When NIHF is suspected to be due to a hematologic cause, and workup for the usual etiologies does not reveal the diagnosis, specialized studies, such as analysis of proteins of the erythrocyte membrane, should be pursued.

In summary, spectrin Providence, in the homozygous state, is associated with fatal hydrops fetalis secondary to severe hemolytic anemia. This anemia is probably due to the markedly reduced ability of spectrin dimers to self-associate into tetramers and higher order oligomers. As a result, the red cell has a membrane that is so unstable that it is not to be able to withstand normal circulatory stress. The presence of $\alpha$-thalassemia trait in the father (Table II) raises the possibility that the severe phenotype of this disorder may be due to the combination of homozygosity for spectrin Providence with heterozygosity for $\alpha$-thalassemia trait. However, the absence and very low level of hemoglobin $(\mathrm{Hb})$ Bart's in cord and fetal blood samples of hydropic infants II-3 and II-4, respectively (Table II), rules out a significant role for $\alpha$-thalassemia trait as a genetic modifier of the severity of the $\beta$-spectrin gene disorder.

\section{Acknowledgments}

We sincerely thank the following individuals for helpful discussions and invaluable assistance in providing clinical information as well as blood samples and other clinical specimens from members of the af- 
fected kindred, without which these studies would not have been possible: Drs. D. Abuelo, M. Carpenter, D. Coustan, J. Crowley, M. J. Mahoney, C. Neave, C. Oyer, R. Sabonya, M. Sloan, P. Smith, and Ms. A. Richardson. We also thank E. Coupal, F. Gillespie, S. Kennedy, and Dr. H. Kliman for skilled technical advice and assistance, and Dr. L. Solomon for performing the red blood cell enzyme assays.

This study was supported in part by grants from the National Institutes of Health, the Charles H. Hood Foundation, and the March of Dimes Birth Defects Foundation.

\section{References}

1. Anderson, H. M., N. A. Beischer, A. A. Hutchison, and D. W. Fortune. 1983. Non-immune hydrops fetalis: changing contribution to perinatal morality. Br. J. Obstet. Gynaecol. 90:636-639.

2. Saltzman, D. H., F. D. Frigoletto, B. L. Harlow, V. A. Barss, and B. R. Benacerraf. 1989. Sonographic evaluation of hydrops fetalis. Obstet. Gynecol. 74:106-111.

3. Hutchison, A. A., J. H. Drew, and D. W. Fortune. 1982. Nonimmunologic hydrops fetalis: a review of 61 cases. Obstet. Gynecol. 59:347-352.

4. Shimokawa, H., K. Hara, H. Maeda, S. Miyamoto, T. Koyanagi, and H. Hakano. 1988. Intrauterine treatment of idiopathic hydrops fetalis. J. Perinat. Med. 16:133-138.

5. Santolaya, J., D. Alley, R. Jaffee, and S. L. Warsof. 1992. Antenatal classification of hydrops fetalis. Obstet. Gynecol. 79:256-259.

6. Ruiz Villaespesa, R., M. P. Suarez Mier, P. Lopez Ferrer, I. Alavrez Baleriola, and J. I. Rodriguez Gonzalez. 1990. Nonimmunologic hydrops fetalis: an etiopathogenetic approach through the postmortem study of 59 patients. Am. J. Med. Genet. 35:274-279.

7. Jauniaux, E., L. Van Maldergem, C. DeMunter, G. Moscoso, and Y. Gillerot. 1990. Nonimmune hydrops fetalis associated with genetic abnormalities. Obstet. Gynecol. 75:568-572.

8. Whitfield, C. F., J. B. Follweiler, L. Lopresiti-Morrow, and B. A. Miller. 1991. Deficiency of $\alpha$-spectrin synthesis in burst-forming units-erythroid in lethal hereditary spherocytosis. Blood. 78:3043-3051.

9. Alloisio, N., P. Texier, A. Forissier, M. L. Ribeiro, L. Morle, M. Bozon, E. Bursaux, P. Maillet, M. J. A. Tanner, and J. Delaunay. 1993. Band 3 Coimbra: a variant associated with dominant hereditary spherocytosis and band 3 deficiency. Blood. 82 (Suppl. 1):4a. (Abstr.)

10. Agre, P., E. P. Orringer, and V. Bennett. 1982. Deficient red-cell spectrin in severe, recessively inherited spherocytosis. N. Engl. J. Med. 306:1155-1161.

11. Agre, P., J. F. Casella, W. H. Zinkham, C. McMillan, and V. Bennett. 1985. Partial deficiency of erythrocyte spectrin in hereditary spherocytosis. Nature (Lond.). 314:380-383

12. Coetzer, T. L., J. Lawler, S.-C. Liu, J. Prchal, R. Gualtieri, M. Brain, J. Dacie, and J. Palek. 1988. Partial ankyrin and spectrin deficiency in severe, atypical hereditary spherocytosis. N. Engl. J. Med. 318:230-234.

13. Tse, W. T., M.-C. Lecomte, F. F. Costa, M. Garbarz, C. Feo, P. Boivin, D. Dhermy, and B. G. Forget. 1990. Point mutation in the $\beta$-spectrin gene associated with $\alpha \mathrm{I} / 74$ hereditary elliptocytosis. J. Clin. Invest. 86:909-916.

14. Dhermy, D., M. Garbarz, M.-C. Lecomte, C. Feo, O. Bournier, I. Chaveroche, H. Gautero, C. Galand, and P. Boivin. 1986. Hereditary elliptocytosis: clinical, morphological and biochemical study of 38 cases. Nouv. Rev. Fr. Hematol. 28:129-140.

15. Coetzer, T., J. Palek, J. Lawler, S. C. Liu, P. Jarolim, M. Lahav, J. T. Prchal, W. Wang, B. P. Alter, G. Schewitz, et al. 1990. Structural and functional heterogeneity of $\alpha$ spectrin mutations involving the spectrin heterodimer selfassociation site: relationships to hematologic expression of homozygous hereditary elliptocytosis and hereditary pyropoikilocytosis. Blood. 75:2235-2244.

16. Gallagher, P. G., W. T. Tse, T. Coetzer, M.-C. Lecomte, M. Garbarz, H. S. Zarkowsky, A. Baruchel, S. K. Ballas, D. Dhermy, J. Palek, and B. G. Forget. 1992. A common type of the spectrin $\alpha \mathrm{I} 46-50 \mathrm{a}-\mathrm{kD}$ peptide abnormality in hereditary elliptocytosis and pyropoikolocytosis is associated with a mutation distant from the proteolytic cleavage site. J. Clin. Invest. 89:892-898.

17. Sahr, K. E., T. L. Coetzer, L. S. Moy, L. H. Derick, A. H. Chishti, P. Jarolim, F. Lorenzo, E. Miraglia del Giudice, A. Iolascon, R. Gallanello, et al. 1993. Spectrin Cagliari. An ALA $\rightarrow$ GLY substitution in helix 1 of $\beta$ spectrin repeat 17 that severely disrupts the structure and self-association of the erythrocyte spectrin heterodimer. J. Biol. Chem. 268:22656-22662.

18. Lux, S. E., and P. S. Becker. 1989. Disorders of the Red Cell Membrane Skeleton: Hereditary Spherocytosis and Hereditary Elliptocytosis. C. R. Scriver, A. L. Beaudet, W. S. Sly, and D. Valle, editors. McGraw-Hill Inc., New York. $2367 \mathrm{pp}$.

19. Delaunay, J., and D. Dhermy. 1993. Mutations involving the spectrin heterodimer contact site: clinical expression and alterations in specific function. Semin. Hematol. 30:21-33.
20. Palek, J., and K. Sahr. 1992. Mutations of the red cell membrane proteins: from clinical evaluation to detection of the underlying genetic defect. Blood. 80:308-330.

21. Dhermy, D. 1991. The spectrin superfamily. Biol. Cell. 71:249-254.

22. Speicher, D. W., and V. T. Marchesi. 1984. Erythrocyte spectrin is composed of many homologous triple helical segments. Nature (Lond.). 311:177180.

23. Yan, Y., E. Winograd, A. Viel, T. Cronin, S. C. Harrison, and D. Branton. 1993. Crystal structure of the repetitive segments of spectrin. Science (Wash. DC). 262:2027-2030.

24. Johnson, R. M. 1975. The kinetics of resealing washed erythrocyte ghosts. J. Membr. Biol. 22:231-241.

25. Mohandas, N., N. R. Clark, B. P. Heath, M. Rossi, L. Wolfe, S. E. Lux, and S. B. Shohet. 1982. A technique to detect reduced mechanical stability of red cell membranes: relevance to elliptocytic disorders. Blood. 59:768-774.

26. Marchesi, S. L., W. J. Knowles, J. S. Morrow, M. Bologna, and V. T. Marchesi. 1986. Abnormal spectrin in hereditary elliptocytosis. Blood. 67:141151.

27. Fairbanks, G., T. L. Steck, and D. F. H. Wallach. 1971. Electrophoretic analysis of the major polypeptides of the human erythrocyte membrane. Biochemistry. 10:2606-2617.

28. Ungewickell, E., and W. Gratzer. 1978. Self-association of human spectrin. A thermodynamic and kinetic study. Eur. J. Biochem. 88:379-383.

29. Speicher, D. W., J. S. Morrow, W. J. Knowles, and V. T. Marchesi. 1980. Identification of proteolytically resistant domains of human erythrocyte spectrin. Proc. Natl. Acad. Sci. USA. 77:5673-5677.

30. Marchesi, S. L., J. T. Letsinger, D. W. Speicher, V. T. Marchesi, P. Agre, B. Hyun, and G. Gulati. 1987. Mutant forms of spectrin $\alpha$-subunits in hereditary elliptocytosis. J. Clin. Invest. 80:191-198.

31. Kiyabu, M. T., D. Shibata, N. Amheim, W. J. Martin, and P. L. Fitzgibbons. 1989. Detection of human papilloma virus in formalin-fixed, invasive squamous cell carcinomas using the polymerase chain reaction. Am. J. Surg. Pathol. 13:221-224.

32. Sahr, K. E., T. Tobe, A. Scarpa, K. Laughinghouse, S. L. Marchesi, P. Agre, A. J. Linnenbach, V. T. Marchesi, and B. G. Forget. 1989. Sequence and exon-intron organization of the DNA encoding the $\alpha$ I domain of human spectrin: application to the study of mutations causing hereditary elliptocytosis. J. Clin. Invest. 84:1243-1252.

33. Tse, W. T., P. G. Gallagher, B. Pothier, F. F. Costa, A. Scarpa, J. Delaunay, and B. G. Forget. 1991. An insertional frameshift mutation of the $\beta$-spectrin gene associated with elliptocytosis in spectrin Nice $(\beta 220 / 216)$. Blood. 78:517-523.

34. Smith, D. B., and K. S. Johnson. 1988. Single-step purification of polypeptides expressed in Escherichia coli as fusions with glutathione $S$-transferase. Gene (Amst.). 67:31-40.

35. Kennedy, S. P., S. L. Warren, B. G. Forget, and J. S. Morrow. 1991. Ankyrin binds to the 15 th repetitive unit of erythroid and nonerythroid $\beta$-spectrin. J. Cell Biol. 115:267-277.

36. Kennedy, S. P., S. A. Weed, B. G. Forget, and J. S. Morrow. 1994. A partial structural repeat forms the heterodimer self-association site of all $\beta$-spectrins. $J$. Biol. Chem. 269:11400-11408.

37. Iarocci, T. A., G. M. Wagner, N. Mohandas, P. A. Lane, and W. C. Mentzer. 1988. Hereditary poikilocytic anemia associated with the co-inheritance of two alpha spectrin abnormalities. Blood. 71:1390-1396.

38. Speicher, D. W., J. S. Morrow, W. J. Knowles, and V. T. Marchesi. 1982 A structural model of human erythrocyte spectrin: alignment of chemical and functional domains. J. Biol. Chem. 257:9093-9101.

39. Morrow, J. S., D. W. Speicher, W. J. Knowles, C. J. Hsu, and V. T. Marchesi. 1980. Identification of functional domains of human erythrocyte spectrin. Proc. Natl. Acad. Sci. USA. 77:6592-6596.

40. Liu, S. C., J. Palek, and J. T. Prchal. 1982. Defective spectrin dimer-dimer association in hereditary elliptocytosis. Proc. Natl. Acad. Sci. USA. 79:20722076.

41. Speicher, D. W., T. DeSilva, K. D. Speicher, J. A. Ursitti, P. Hembach, and L. Weglarz. 1993. Location of the human red cell spectrin tetramer binding site and detection of a related "closed" hairpin loop dimer using proteolytic footprinting. J. Biol. Chem. 268:4227-4235.

42. Winkelmann, J. C., J.-G. Chang, W. T. Tse, V. T. Marchesi, and B. G. Forget. 1990. Full length sequence for the human cDNA for human erythroid $\beta$ spectrin. J. Biol. Chem. 265:11827-11832.

43. Amin, K. M., A. L. Scarpa, J. C. Winkelmann, P. J. Curtis, and B. G. Forget. 1993. The exon-intron organization of the human erythroid $\beta$-spectrin gene. Genomics. 18:118-125.

44. Pothier, B., L. Morle, N. Alloisio, M. T. Ducluzeau, C. Caldani, C. Feo, M. Garbarz, I. Chaveroche, D. Dhermy, M. C. Lecomte, et al. 1987. Spectrin Nice $\left(\beta^{220 / 216}\right)$ : a shortened $\beta$-chain variant associated with an increase of the $\alpha^{1 / 74}$ fragment in a case of elliptocytosis. Blood. 69:1759-1765.

45. Dhermy, D., M. C. Lecomte, M. Garbarz, O. Bournier, C. Garland, H. 
Gautero, C. Feo, N. Alloisio, J. Delaunay, and P. Boivin. 1982. Spectrin $\beta$-chain variant associated with hereditary elliptocytosis. J. Clin. Invest. 70:707-715.

46. Gallagher, P. G., W. T. Tse, F. Costa, A. Scarpa, P. Boivin, J. Delaunay, and B. G. Forget. 1991. A splice site mutation of the $\beta$-spectrin gene causing exon skipping in hereditary elliptocytosis associated with a truncated $\beta$-spectrin chain. J. Biol. Chem. 266:15154-15159.

47. Garbarz, M., W. T. Tse, P. G. Gallagher, C. Picat, M.-C. Lecomte, F. Galibert, D. Dhermy, and B. G. Forget. 1991. Spectrin Rouen $\left(\beta^{220-218}\right)$, a novel shortened $\beta$-chain variant in a kindred with hereditary elliptocytosis. Characterization of the molecular defect as exon skipping due to a splice site mutation. $J$. Clin. Invest. 88:76-81.

48. Lecomte, M. C., H. Gautero, O. Bournier, C. Galand, A. Lahary, J. P. Vannier, M. Garbarz, J. Delaunay, G. Tchernia, P. Boivin, and D. Dhermy. 1992 Elliptocytosis-associated spectrin Rouen $\left(\beta^{220 / 218}\right)$ has a truncated but still phosphorylatable $\beta$ chain. Br. J. Haematol. 80:242-250.

49. Kanzaki, A., M. Rabodonirina, Y. Yawata, R. Wilmotte, H. Wada, K Ata, O. Yamada, J. Akatsuka, H. Iyori, M. Horiguchi, et al. 1992. A deletiona frameshift mutation of the $\beta$-spectrin gene associated with elliptocytosis in spectrin Tokyo $\left(\beta^{220 / 216}\right)$. Blood. 80:2115-2121.

50. Garbarz, M., L. Boulanger, S. Pedroni, M. C. Lecomte, H. Gautero, C. Galand, P. Boivin, L. Feldman, and D. Dhermy. 1992. Spectrin $\beta^{\text {Tandil }}$, a novel shortened $\beta$-chain variant associated with hereditary elliptocytosis is due to a deletional frameshift mutation in the $\beta$-spectrin gene. Blood. 80:1066-1073.

51. Mentzer, W. C., T. A. Iarocci, N. Mohandas, P. A. Lane, B. Smith, L. Lazerson, and T. Hays. 1987. Modulation of erythrocyte membrane stability by 2,3-diphosphoglycerate in the neonatal poikilocytosis/elliptocytosis. J. Clin. Invest. 79:943-949.

52. Mentzer, W. C., T. Turetsky, N. Mohandas, S. Schrier, C.-S. C. Wu, and H. Koenig. 1984. Identification of the hereditary pyropoikolcytosis carrier state. Blood. 63:1439-1446.

53. Lane, P. A., R. L. Shew, T. A. Iarocci, N. Mohandas, T. Hays, and W. C. Mentzer. 1987. A unique alpha spectrin mutant in a kindred with common hereditary elliptocytosis. J. Clin. Invest. 79:943-949.

54. Yoon, S.-H., H. Yu, S. Eber, and J. T. Prchal. 1991. Molecular defect of truncated $\beta$-spectrin associated with hereditary elliptocytosis. $\beta$-spectrin Gottingen. J. Biol. Chem. 266:8490-8494.

55. Hu, R.-J., M. Watanabe, and V. Bennett. 1992. Characterization of human brain cDNA encoding the general isoform of $\beta$-spectrin. J. Biol. Chem. 267:18715-18722.

56. Tan, S., V. Shankar, and M. S. Gilmore. 1993. Nucleotide sequence of a cDNA for canine $\beta$-spectrin reveals high evolutionary conservation. Biochim. Biophys. Acta. 1172:217-219.

57. Bloom, M. L., C. S. Birkenmeier, and J. E. Barker. 1993. Complete nucleotide sequence of the murine erythroid $\beta$-spectrin cDNA and tissue-specific expression in normal and jaundiced mice. Blood. 82:2906-2914.

58. Ma, Y., W. E. Zimmer, B. M. Riederer, and S. R. Goodman. 1993. The complete amino acid sequence for brain $\beta$ spectrin ( $\beta$ fodrin): relationship to globin sequences. Mol. Brain Res. 18:87-99.

59. Chou, P. Y., and G. D. Fasman. 1978. Prediction of the secondary structure of proteins from their amino acid sequence. Adv. Enzymol. Relat. Areas Mol. Biol. 47:45-148. 